\title{
1 Development of intermediate layer systems for direct 2 deposition of thin film solar cells onto low cost steel \\ 3 Substrates
}

4 M.F Menéndez ${ }^{1}$, A. Martinez ${ }^{1}$, P. Sánchez ${ }^{1}$, D. Gomez ${ }^{2}$, L.J. Andrés ${ }^{2}$, L. Haponow ${ }^{3}$, N.

5 Bristow $^{3}$, J. Kettle $^{3}$, T. Korochkina ${ }^{4}$, D.T. Gethin ${ }^{4}$

6 1. Idonial Foundation, C/ Calafates, 33417 Avilés, Spain

7 2. ITMA Foundation, C/ Calafates, 33417 Avilés, Spain

8 3. School of Computer Science and Electronic Engineering, Bangor University, Bangor,

9 Gwynedd LL57 2UT, UK

10 4. WCPC, Swansea University Bay Campus, Swansea, UK

\begin{abstract}
The functionalisation of low-cost steel over large areas with low cost intermediate layers (ILs) for utilisation as substrates in thin film solar modules is reported. Three approaches for the deposition of ILs are demonstrated and evaluated; a thick $\mathrm{SiO}_{\mathrm{x}}$ sol-gel based on a one-step acidic catalysis applied by spray technique, a commercial screen-printable dielectric ink, and an epoxybased material (SU8) deposited by screen printing or bar coating. These ILs demonstrated the properties of surface levelling (quantified by mechanical profilometry), electric insulation (tested using breakdown voltage and leakage current) and acted as an anti-diffusion barrier (demonstrated with glow discharge mass spectrometry). Moreover, the performances of amorphous silicon (a$\mathrm{Si}: \mathrm{H})$ and organic photovoltaic (OPV) thin film solar cells grown on carbon and stainless steels (a-Si:H: 5.53\% and OPV: 2.40\%) show similar performances as those obtained using a reference glass substrate (a-Si:H: $5.51 \%$ and OPV: $2.90 \%$ ). Finally, a cost analysis taking into account both the $\mathrm{SiO}_{\mathrm{x}}$ sol-gel and the dielectric ink IL was reported to demonstrate the economic feasibility of the steel/IL prototypes.
\end{abstract}




\section{Introduction}

Building Integrated Photovoltaics (BIPV) has emerged as an important strategy for domestic energy production with commercial interest driven by the EU's 2020 targets [1, 2] and the consideration that all new buildings should be nearly zero-energy by the end of 2020. Although BIPV still represents a small share of the photovoltaic (PV) market, a number of demonstrators have shown the feasibility of BIPV systems and their superiority over conventional roof installation (Building Attached Photovoltaics (BAPV)) approaches in terms of overall cost and aesthetics [3, 4]. BIPV concepts have been applied within a diverse range of building sector products including for public/commercial and domestic buildings, both for retrofitting and for new buildings (see, for example, [5]).

Most BIPVs are made using silicon-based materials; however, further improvements in product innovation and cost are still required in order to compete with mainstream PV technologies. As a result a number of different authors $[6,7,8,9]$ have proposed: (i) the integration of thin film solar cells (TFSC) as alternatives to crystalline silicon (c-Si), and (ii) the development of BIPVs directly onto conventional building materials instead of glass substrates.

In order to introduce the TFSC technology in the market in a competitive fashion, a number of challenges need to be overcome. Firstly, there is a need to demonstrate the feasibility of low-cost substrates that are already using by the construction industry; for example to adopt steel substrates, low cost alternatives are need as existing work is based on expensive "solar-grade" stainless steel (SS), which is too costly for the construction industry. Therefore, it is more cost effective if existing construction material is adapted for BIPV usage, but this requires specific preparation of the steel surface. The preferred solution is the use of an intermediate layer (IL) system between the steel and the TFSC. The steel industry has substantial experience of coating insulating layers so this is a feasible option for implementation. The main requirements for this IL layer are: (i) to smooth the steel surface in order to prepare it for the application of TFSC nanolayers and to prevent direct short-cuts in the future integrated solar cells; (ii) to prevent the diffusion of chemical elements (e.g. $\mathrm{Fe}, \mathrm{Cr}, \mathrm{Ni}$, etc.) from the steel to the TFSC during the solar cell process fabrication; (iii) to electrically insulate the TFSC back contact electrode from the steel substrate to allow the development of TFSC modules by the interconnection of monolithic serial cells using laser ablation scribing processes; and (iv) to be stable and 
not delaminate during post-processing for semiconductor layer deposition as well as during storage.

Recently, several works concerning IL system deposition on steel substrate to develop chalcopyrite (CIGS) or silicon TFSC have been reported. Whilst promising, their work used relatively thin IL which are unlikely to be scalable for solar modules. L. Zortea et al. [10] investigated the behavior of an electroplated bi-layer ( $\mathrm{Ni}$ and $\mathrm{Cr}$ ) on a mirror surface finished (average roughness, $\mathrm{R}_{\mathrm{a}}<0.1 \mu \mathrm{m}$ ) mild steel foil. Kyoung-Bo et al. [11] developed monolithic CIGS on SS applying, by screen-printing, a $10 \mu \mathrm{m}$ silicon dioxide $\left(\mathrm{SiO}_{2}\right)$ IL. However, the resulting $\mathrm{R}_{\mathrm{a}}$ was $0.21 \mu \mathrm{m}$ and only poor levelling was achieved through the sol-SiO${ }_{2}\left(\mathrm{R}_{\mathrm{a}}=0.157 \mu \mathrm{m}\right)$. Thongkham et al.[12] applied aluminum oxide $\left(\mathrm{Al}_{2} \mathrm{O}_{3}\right)(2 \mu \mathrm{m}$ thick) by physical vapour deposition (PVD) on different SS substrates (types 301, 316L and 430) and reported a very poor adhesion due to the different coefficient thermal expansions (CTE) of the IL compared to the CIGS thin films.

Concerning silicon based TFSC, Yun et al. [13] developed $\mathrm{SiO}_{2}$ and $\mathrm{Al}_{2} \mathrm{O}_{3} / \mathrm{SiO}_{2}$ sol-gel stack as IL for SS. The results showed poor adhesion of the layers and etching the surface with hydrochloric $(\mathrm{HCl})$ acid solution prior to application of the IL was needed to increase the roughness and improve the adhesion. Lee et al. [14] reported the improvement of the performance of silicon TFSC on SS substrate by an electrochemical mechanical polishing method. This process created chromium oxide $\left(\mathrm{Cr}_{2} \mathrm{O}_{3}\right)$ and iron oxide $\left(\mathrm{Fe}_{2} \mathrm{O}_{3}\right)$ passive films which act as anti-diffusion layers, blocking $\mathrm{Cr}$ and $\mathrm{Fe}$ diffusion into the silicon TFSC. However, electrical insulation was not achieved using these passive films. Martinez et al [9] developed a $\mathrm{SiO}_{\mathrm{x}}$ sol-gel multilayer to make automotive hot-dip galvanized steel compatible with amorphous silicon (a-Si:H) TFSC. A power conversion efficiency (PCE) of $3.03 \%$ was achieved, but the scalability to larger areas was not addressed. Lopez et al [15] combined $\mathrm{SiO}_{\mathrm{x}}$ sol-gel and $\mathrm{SiO}_{\mathrm{x}}$ plasma enhanced chemical vapor deposition (PECVD) films in two and three layers stacks on SS foils, reporting highly dielectric properties (breakdown voltages $>900 \mathrm{~V}$ ) and compatibility with CIGS TFSCs.

In general, CIGS and silicon-based thin film technologies are the most widely reported and mature PV systems which have been developed onto steel substrates, although there have also been some attempts with dye sensitized [16], cadmium tellurite [17], organic photovoltaic (OPV) [18-21], and kesterite solar cells [22]. Many of the reports, such as Ding et al [21] were focused on non-scalable approaches to IL deposition for OPVs using 
spin-coating. As OPVs are likely to made commercially by roll-to-roll (R2R) production methods, similar processing strategies must be adopted for the application of ILs.

As can be seen in the works above, steel/IL systems show several drawbacks for an industrial application, such as the necessity to process the steel surface to reach a very low roughness [10, 14], poor IL adhesion [12, 13], the lack of electrical insulation [14], and the difficulty in implementing multilayer stacks $[9,15]$.

Moreover, most of these examples use relatively expensive steels (e.g. stainless and only very thin substrates, around $25 \mu \mathrm{m}$ thick), and in most of these cases the up-scaling of the process in terms of manufacturing yield, potential or cost is rarely reported. This creates a paradoxical situation; by using an expensive steel substrate, the end product is difficult to be introduced to the building sector, as it is more common to use a lower cost steel such as dipped or galvanised low carbon steels for building infrastructure.

In this paper several low-cost IL strategies (ceramic sol-gel and polymer-based) deposited onto low-cost structural steel grades are reported. The developments were carried out with the view to possible further industrial application, so only single layer IL strategies were pursued to make compatible steel substrates and TFSC. In that sense, one challenge of the present work concerned the sol-gel IL, as its main drawback is that its maximum achievable thickness without stress cracks forming is low (typically, $1 \mu \mathrm{m}$ ).

In addition, only high throughput coating techniques were employed in order to demonstrate the potential for upscaling the approach. The IL systems were characterised morphologically and electrically, and different TFSC (a-Si:H and OPV) were grown and compared with glass substrates as reference to demonstrate the feasibility of our approach for the thin-film solar community. The results show that the behaviour of amorphous silicon cells and OPVs on intermediate layers of SiOx sol-gel and SU8, respectively, are indistinguishable from cells grown on glass, which constitutes the most innovative part of this work.

\section{Experimental}

\subsection{Substrate selection}

The initial selection of steel substrates has been made by consideration of four main factors: (i) chemical inertness, (ii) thermal coefficient of expansion with respect to the IL 
materials, (iii) surface quality in terms of absence of defects and low initial roughness, and (iv) pre-existing usage within the construction sector.

Four steels were selected which met these criteria: a bare low carbon steel (DC01), two hot-dipped metallic low carbon steels (zinc-coated DX51D $+Z$ and aluminium-silicon coated DX51D+AS) and a ferritic stainless steel (AISI430). Chemical composition of each type is given in Table I. Initially, all the steels were rolled by high speed steel (HSS) grinding rolls in order to reduce the initial peak to-peak $\left(\mathrm{R}_{\mathrm{z}}\right)$ surface roughness down to $1.3 \mu \mathrm{m}$. This roughness value was considered as a good compromise between the rolling cost and the intermediate layer approach considered. The steels were rolled to a thickness of $0.3 \mathrm{~mm}$ as this is compatible with lab-scale coating techniques and leads to a 10 times reduction in the steel costs when compared to the industrial standard stainless steel used in previous attempts to integrate steel and TFSCs [23].

\subsection{Intermediate layer (materials, processes and characterization)}

Once the steel substrates were prepared, ILs were applied to fulfil the following requirements: (i) to level and minimize the surface roughness for high quality thin film solar deposition, (ii) to electrically isolate the steel substrate for safety and to enable monolithic integration, (iii) to act as a barrier for ionic diffusion and to avoid TFSC contamination from the steel, (iv) to give thermal and mechanical stability to the PV cell or module above the steel substrate, (v) to show a long shelf life during storage, and (vi) to be compatible with subsequent PV deposition processes. The selected ILs and the deposition methods are listed below:

\subsection{2 $\mathrm{SiO}_{\mathrm{x}}$-based sol-gel coatings}

\subsubsection{Sol-gel synthesis}

Sol-gel is a well-established technology for thin-film coatings in the steel industry; materials are applied in a mixture that leads to a hydrolysis-condensation of the precursors and enables coatings through low cost/temperature deposition techniques. Sol-gel technology offers a good control of the thickness and a high degree of homogeneity through the creation of an inorganic matrix. The main drawback for sol-gel is that its maximum achievable thickness without stress cracks forming is low (typically, $1 \mu \mathrm{m}$ ). Cracks are mainly produced during evaporation of solvents due to mechanical and 
thermal stresses between the layer and the substrate. The introduction of tension releasing agents in sol-gel matrixes constitutes an interesting approach to reduce cracking and increase coating thickness. Special attention to this strategy has been considered in this work. In this work, the sol-gel formulation followed a one-step acid catalysis using methyltriethoxysilane (MTES 99\%, Aldrich) and tetraethyl orthosilicate (TEOS 98\%, Aldrich) as precursors. Water was incorporated as a solvent, polyethylene glycol 6000 (PEG-6000, Panreac) as a tension releasing agent and $\mathrm{HNO}_{3}$ as a catalyst. The molar ratios were optimised in order to reach a suitable homogeneity, adhesion and pin-hole free layer after application and curing. These were TEOS/MTES: 1.35, $\mathrm{H}_{2} \mathrm{O}$ /(MTES+TEOS): 4.7, and PEG-6000/(MTES+TEOS): 0.02. The synthesis was carried out at room temperature with vigorous magnetic stirring. The addition of $\mathrm{HNO}_{3}$ initiates the hydrolysis, increasing the temperature by $25^{\circ} \mathrm{C}$. During the sol phase preparation, the ambient conditions have been controlled, being the average temperature registered of $23^{\circ} \mathrm{C}$ and the relative humidity of $48 \%$. This sol mixture was aged for one hour under stirring before application.

\subsubsection{Sol-gel deposition and curing}

Spray coating was performed with a commercial air atomizing spray gun (Spraying Systems Inc.) with a nozzle cone angle of $60^{\circ}$. It was mounted on an automatized spray system and moved transversely with respect to the sample movement. The $30 \mathrm{~cm} \times 30 \mathrm{~cm}$ samples were coated using the following parameters: (i) $\mathrm{SiO}_{\mathrm{x}}$ sol-gel dilution 1:0.5 in ethanol, (ii) a sol-gel liquid pressure between $0.4 \mathrm{bar}$ and $0.5 \mathrm{bar}$, (iii) a holder speed of $1.6 \mathrm{~m} / \mathrm{min}$, (iv) a nozzle/sample distance of $8 \mathrm{~cm}$, and (v) a one scan spray.

Curing was carried out by means of near-infrared (NIR) technique. The fast heating of the steel substrate combined with the relative transparency of the sol-gel film to NIR radiation allows a rapid, indirect annealing of the sol-gel layer. In addition, the prospect of curing from the inner to the outer part of the coating enables a correct extraction of the solvents. The experiments were performed using a NIR equipment (AdPhos, model 336250) composed of eight NIR lamps (0.8kW each) each $250 \mathrm{~mm} \times 42 \mathrm{~mm}$, which outputs a maximum power density of $76 \mathrm{~kW} / \mathrm{m}^{2}$. The distance between the NIR lamps and the steel/IL prototypes was kept constant at $20 \mathrm{~cm}$ and the process was developed in sheet-tosheet mode. At an irradiation power of $90 \%$, a cure time of 2 minutes was applied in all 
cases (reaching a peak metal temperature of $198^{\circ} \mathrm{C}$ ), which represents a clear time reduction when compared to conventional hot-plate curing (close to one hour, typically).

In order to study the suitability of the sol-gel coatings for the coating of selected steels, the surface tension was measured using a Dynamic Absorption and Contact Angle Tester (FIBRO DAT 1100), and showed a value of $26.19 \pm 0.14 \mathrm{mN} / \mathrm{m}$. Under the same experimental technique, the surface free energy of the four steel substrates was also evaluated using the Owens-Wendt-Rabel-Kaelble method. The values obtained were between $38 \mathrm{mN} / \mathrm{m}$ and $40 \mathrm{mN} / \mathrm{m}$ for all steel types, and confirm the suitability of the sol formulation for coating onto these steels. Additionally, viscosity has been calculated using a Bohlin-Gemini rheometer. The obtained value was $0.005 \mathrm{~Pa}$.s at $230 \mathrm{1} / \mathrm{s}$. This ensures the solution is suitable for dip and spray coating technologies and should lead to relatively thin coatings.

\subsubsection{Organic commercial coatings}

Organic coatings have also been trialled as ILs. These materials allow easier processing, thicker coatings with better dielectric behaviour and potentially better planarization. Organic materials were sought on the basis of the following priorities: low cost, proven dielectric properties and usage in other industries i.e. electronics, printability/coatability, good insulation and good adhesion to substrates. Two materials were trialed:

\subsubsection{Blue Ink}

Blue Ink is a commercially available dielectric ink also known as 'blue dielectric paste' (D2140114D5) from Sun Chemical, USA. This material was screen printed by means of a sheet-to-sheet semi-automated system (DEK248) suitable for handling $35 \mathrm{~cm} \mathrm{x} 35 \mathrm{~cm}$ (up to $6 \mathrm{~mm}$ thick) steel sheets. The layers were applied directly onto the steel through square stencils. After coating, the ink layer was then dried using a hot air conveyor dryer at $150^{\circ} \mathrm{C}$ for 20 minutes.

\subsubsection{SU-8}

SU-8 is an epoxy-based material, which contains a bisphenol A novalac epoxy that is dissolved in cyclopentanone and mixed with $10 \%$ of mixed triarylsulfonium salt which acts as the photoacid generator. It is widely used in the microelectronics and micro electro mechanical systems (MEMS) industry as it crosslinks under ultra-violet (UV) irradiation. After coating it can provide a suitable interface between a steel substrate and a PV cell. 
217 The SU-8 epoxy layer (the formulation used is SU8-2050, supplied from Chestech ltd., 218 UK) was bar coated onto the steel samples (size $18 \mathrm{~mm} \times 18 \mathrm{~mm}$ ). In contrast to the earlier work of Ding et al [21], the SU-8 deposition approach is scalable to larger areas, therefore potential enabling module production. The film was then cured at $150^{\circ} \mathrm{C}$ for 15 minutes then hard baked at $250^{\circ} \mathrm{C}$ for 10 minutes.

\subsubsection{Characterization of the steel/IL systems}

224

Three main characterization techniques have been considered in this work. Firstly, the impact of the IL on surface roughness, which has been determined through roughness analysis by mechanical profilometry (Model XP-1, Ambios Technology, USA). Profilometry was selected for surface roughness measurements because it allows for surface roughness measurements to be conducted over large areas. A large surface area needs to be mapped because a small number of surface topography issues could lead to electrical shortages. Profilometry allows for large processing anomalies to be identified, but also allows for the surface roughness to be accurately characterized as the resolution of our system is $5 \AA$.

Secondly, the anti-diffusive behaviour of the layer has been characterized by solid state Glow Discharge Time of Flight Mass Spectrometer (GD-ToF-MS). GD sources coupled to MS provides rapid and highly sensitive characterisation of major and trace elements in homogeneous solids as well as depth profiling analysis of coating materials [24]. The radiofrequency (rf) GD-ToFMS instrument consists of a rf-GD bay unit from Horiba Jobin Yvon coupled to a fast orthogonal time-of-flight mass spectrometer (Tofwerk) with a microchannel plate detector [25]. A pure copper modified Grimm-type GD source (EMPA), with a $4 \mathrm{~mm}$ diameter anode and a $2.5 \mathrm{~mm}$ inner diameter flow tube was used. The power is supplied to the GD through the back side of the sample by an rf-power generator operating at $13.56 \mathrm{MHz}$. Experimental conditions (120 Pa argon discharge pressure, $70 \mathrm{~W}$ rf forward power) were chosen as a compromise between high sensitivity and good depth resolution. Finally, the dielectric behaviour has been analysed. Two approaches were developed. Concerning the breakdown voltage, aluminium (Al) pads $\left(1 \mathrm{~cm}^{2}\right)$ have been first deposited by thermal evaporation (Pfeiffer, model Classic 500) on the IL using a shadow mask. The tests were then performed varying a voltage in a range of $0 \mathrm{~V}$ to $53 \mathrm{~V}$ (using a direct current source) between a copper probe connected to the 
steel substrate and another probe placed onto the metallic Al pad. The breakdown voltage occurs when visual shunts suddenly appear at the IL surface. This simple check also verifies the IL quality by detection of defects such as small voids/cracks; if this were the case, the breakdown voltage occurs at very low values $(<10 \mathrm{~V})$. To evaluate the maximum voltage which the IL will have to endure, a value of $40 \mathrm{~V}$ has been chosen considering $30 \mathrm{~cm} \times 30 \mathrm{~cm}$ panels, typical $1 \mathrm{~cm}$ width serial interconnected cells, output voltages of current thin film commercial modules and by applying a security factor of $50 \%$ overvoltage. A second method to determine the dielectric behaviour of the ILs has been through the measurement of the leakage current. Although this test requires a low current source measurement unit, it enables a quantification of the IL insulation. For these tests, aluminium electrodes have been deposited in a thermal evaporator (Edwards 306). A shadow mask was used to define an active area for the electrodes. A Keithley 237 High Voltage Source Measurement Unit (SMU) was used to measure the leakage current between the back electrode and steel substrate. The bias range was selected from -50V to $+50 \mathrm{~V}$ and the SMU is capable of measuring leakage current at a resolution of $10^{-13} \mathrm{~A}$. Small contact areas were used (5mm diameter circle) and contacted using electrical probing.

\subsection{PV technologies}

\subsubsection{Amorphous silicon}

Amorphous silicon solar cells were manufactured onto steel with an n-i-p a-Si:H structure, instead of the more commonly used p-i-n junction configuration, which is widely adopted for transparent substrates (see Figure 1a and Figure 1b). The bottom and top electrode materials have been reversed in order to improve their electrical conductivity and the electron extraction. Therefore, a bottom electrode of aluminium ( $\mathrm{Al})$ and indium tin oxide (ITO) was chosen. The Al and ITO layers were deposited by thermal evaporation (Pfeiffer 500 System) and rf sputtering (AJA International, model ATC Orion $8 \mathrm{HV})$, respectively. Both processes were performed at room temperature. ITO samples were measured for transparency using UV-NIR spectrophotometry (Avantes, model AvaSpec2048-USB2) with the wavelength range from 400nm to 800nm. Transmittance higher than $90 \%$ was achieved in all cases. ITO sheet resistance $\left(R_{s}\right)$ was determined by 
the four-point probe method (Lucas-Signatone, model Pro4) and values of $20 \Omega / \square$ and $8 \Omega / \square$ respectively for back and front contacts.

The n-i-p a-Si:H layers were deposited by (Very-High Frequency) VHF-PECVD in a cluster configuration system which has separate chambers for the deposition of intrinsic, n-type and p-type layers in order to avoid cross contamination (Elettrorava, model V0714). The silicon deposition process was performed using a plasma gas reaction using $\mathrm{SiH}_{4}$ as the plasma gas and applying a power density of $16 \mathrm{~mW} / \mathrm{cm}^{2}$ at a fixed frequency of $13.56 \mathrm{MHz}$. The gas mixtures, the substrate temperature and the chamber pressure during the n-i-p layers are detailed in previous work [9]. In order to achieve better extraction of the generated electrons, a silver grid busbar was deposited on the top ITO electrode in the samples. All samples were made with an active area of $1 \mathrm{~cm}^{2}$.

The performance of the a-Si:H TFSC was determined by measuring the power conversion efficiency (PCE) from current-voltage (I-V) curves generated by the TFSC devices under global AM1.5G spectrum $\left(1000 \mathrm{~W} / \mathrm{m}^{2}, 25^{\circ} \mathrm{C}\right)$ solar simulator (Oriel, model 91193) through the standard IEC 60904-3:2008. In parallel to a-Si:H TFSC grown on our steel/IL samples, n-i-p inverted cells were also manufactured on glass substrate as a reference. This configuration allows us to benchmark the performance of PVs made on IL-coated steel with those made on the more conventional glass substrate and provide information to the PV community about the relative performance of PVs on steel as opposed to glass. All reported performances are averaged from 6 devices.

\subsubsection{Organic Photovoltaics}

OPVs were fabricated on IL coated steel substrates composed of an opaque bottom electrode, a thin-film semiconductor, and a transparent top electrode (see Figure 1c). For device fabrication, a similar process to the work of Ding et al. was used [21] with the following inverted layer structure: Steel-Al-Cr-ZnO/-3HT:PCBM-CLEVIOS HTLAgNW. The IL coated substrates were used for the deposition of the solar cell. Al/Cr metal back electrodes were thermally evaporated onto the steel/IL system through a shadow mask in an Edwards 306 thermal evaporator. A zinc oxide electron transporting layer was deposited from zinc acetate dehydrate $(109 \mathrm{mg})$ dissolved in 2-methoxyethanol $(1 \mathrm{ml})$ and ethanolamine $(0.03 \mathrm{ml})$ solution. This was spin-coated on the metal electrode and annealed in the presence of atmospheric air at $150^{\circ} \mathrm{C}$ for the zinc acetate to calcinate 
into zinc oxide. Initially, active layer blends using poly(3-hexylthiophene) (P3HT) and

313 [6,6]-Phenyl-C61-butyric acid methyl ester (PCBM) with weight ratios 5:4 were prepared and mixed with chlorobenzene solvent with a concentration of $40 \mathrm{mg} / \mathrm{ml}$, and allowed to dissolve for 24 hours on a hot plate at $60^{\circ} \mathrm{C}$. Samples were stored in a nitrogen atmosphere glovebox $\left(\left[\mathrm{O}_{2}\right]<1 \mathrm{ppm},\left[\mathrm{H}_{2} \mathrm{O}\right]<100 \mathrm{ppm}\right)$, where the active layer was applied by spincasting from the $60^{\circ} \mathrm{C}$ solution to form a 220nm layer. This is thicker than earlier work and is required in order to ensure higher yield as the $\mathrm{SiOx}$ sol-gel layers create more roughness prior to solar cell deposition. The active layer was annealed at $140^{\circ} \mathrm{C}$ for 30 minutes before the hole transport layer (HTL, i.e. Clevios HTL PEDOT) was spin-coated at 4000rpm. The transparent top electrodes were fabricated by spray coating PH1000 PEDOT:PSS (purchased from Ossila ltd., UK) and $0.5 \mathrm{mg} / \mathrm{ml}$ silver nanowire (Ag NW) (L-50, purchased from ACS Materials Inc, USA) in ethanol subsequently onto the HTL in a fume hood through a shadow mask with an air brush. All samples were made with an active area of $1 \mathrm{~cm}^{2}$ and the results presented are averaged from 6 devices.

Alongside the OPVs on steel substrates, conventional inverted cells were manufactured on ITO coated glass substrates. The properties of the ITO-glass were: Rs $=18 \Omega / \square$, transparency $=84 \%$ with glass, transparency $=94 \%$ without glass, and were purchased from Xinyan Ltd. The samples were cleaned using deionised water, acetone and isopropanol in an ultrasonic cleaner and then treated in a UV-ozone reactor with oxygen plasma for 10 minutes and were then used to fabricate OPVs with the following layer structure: ITO/ZnO/P3HT:PCBM/CLEVIOS HTL/Ag. Except for the ITO and the thermally evaporated Ag top electrode, all the other layers were the same as opaque steel substrate cells. As with the a-Si:H cells, the reference sample provides a comparison between PVs made on steel substrates with conventional processing routes. In addition, testing was conducted using the methodology explained in the a-Si section.

\section{Results and discussion}

\subsection{Levelling and barrier properties of ILs on steel}

The three IL coatings were applied onto the four selected steels types, leading to 12 steel/IL combinations. The optimised deposition procedure is highlighted in section 2 for the different layers. The measured thicknesses of the IL coatings were independent of the steel substrate and were between $3-4 \mu \mathrm{m}$ for sprayed sol-gel coatings, $\sim 30 \mu \mathrm{m}$ for the BlueInk and $\sim 70 \mu \mathrm{m}$ for SU8. Thicknesses were initially measured using profilometry, 
but confirmed with cross-sectional field emission secondary electron microscopy (FESEM) as shown in figure 2. The images show the consistency of the IL layers with low surface roughness and are virtually defect free in the bulk. For the organic layers, a moderate optimisation process was needed in order to apply the materials onto steel substrates. However, for sol-gel coatings, a significant optimisation was required to ensure that the right combination of formulation and process spray parameters were used to obtain a consistent and robust coating. However, once fully optimised, the process was readily reproducible and the results explained herein are based upon the optimised deposition processes reported in section 2 .

For all IL coatings, it is observed that a significant reduction in surface roughness is achieved when compared to the initial roughness of the substrate. Figure 3 shows the measured average roughness $\left(R_{a}\right.$, Figure $\left.3(a)\right)$ and peak-to-valley roughness $\left(R_{z}\right.$, Figure 3(b)) for all the systems, denoting a clear reduction of these parameters when the IL are deposited. Based upon results conducted for this paper, we estimate that a reduction of $R_{a}$ to $<60 \mathrm{~nm}$ and $\mathrm{R}_{\mathrm{z}}$ below $<300 \mathrm{~nm}$ is needed for high performing a-Si:H and OPV solar cell deposition. However, the performance of OPVs seem more sensitive to high roughness, so in this case SU8 represents the best choice since this coating material has led to $\mathrm{R}_{\mathrm{a}}<15 \mathrm{~nm}$ and $\mathrm{R}_{\mathrm{z}}<90 \mathrm{~nm}$.

Concerning dielectric isolation, Table II summarizes the obtained results for all the steel/IL systems in terms of leakage current after the voltage breakdown test. As it can be seen, leakage currents are below $50 \mathrm{nA} / \mathrm{cm}^{2}$ for all the samples.

Further studies were conducted to evaluate whether the IL layers limit the impurity diffusion from the steel into the PV device. Figure 4 shows qualitative depth profiles of the steel substrates coated with the $\mathrm{SiO}_{\mathrm{x}}$ sol-gel IL and an $\mathrm{Al}$ electrode to replicate the back contact of a solar cell. This electrode has been deposited in order to study reverse diffusion from the back contact through the $\mathrm{SiO}_{\mathrm{x}}$ layer, and potentially into the solar cell. For each steel/ $/ \mathrm{SiO}_{\mathrm{x}} / \mathrm{Al}$ system, a comparison between a non-annealed and an annealed process has been carried out. The annealing process was dictated by the thermal processes needed for the TFSC technologies considered in this work; therefore, the timetemperature cycle $\left(150 \mathrm{~min}\right.$ at $\left.210^{\circ} \mathrm{C}\right)$ for a-Si:H has been selected as the annealing cycle because it represents the most demanding annealing condition. 
For each qualitative depth profile, the $\mathrm{Al}$ layer shows an abrupt interface with the $\mathrm{SiO}_{\mathrm{x}}$ coating. As the sputtering time increases, there is an increase in the silicon and oxygen content; an increase in carbon is also observed, owing to the PEG releasing agent that has not been fully degraded at the $210^{\circ} \mathrm{C}$ curing temperature.

Related to the DC01, DX51D+AS and AISI430 substrates, it is clearly observed that no steel element $(\mathrm{Fe}, \mathrm{Cr})$ and $\mathrm{Al} / \mathrm{Si}$ elements from the metallic coating are diffusing into the $\mathrm{SiO}_{\mathrm{x}}$ sol-gel, demonstrating that this IL limits the diffusion of unwanted impurities from the steel into the PV structure. Concerning the DX51D+Z substrate, a minor diffusion of the zinc is present, although this is unlikely to interfere with the Al back contact due to the low intensity and penetration depth. It is also observed that no diffusion of Al into the steel substrates is apparent, so it appears that the $\mathrm{SiO}_{\mathrm{x}}$ sol-gel layer does act as an ionic blocking layer in both directions. These qualitative in-depth profiles also show the levelling effect of the $\mathrm{SiO}_{x}$ coating. All the profiles possess an abrupt interface between the $\mathrm{Al}$ and $\mathrm{SiO}_{\mathrm{x}}$, but the corresponding $\mathrm{SiO}_{\mathrm{x}} /$ steel interface is extended indicating a much rougher surface finish on the steel.

The anti-diffusion behaviour of the organic coatings, i.e. the BlueInk, has been also studied under the same experimental conditions as above. For this coating, the elemental identification is much more complex due to the highly insulative behaviour of the coating which limits the signal into the mass spectrometer until the depth profiling has reached the steel substrate. However, it is possible to infer from the data that no elements from the steel are diffusing through the dielectric, which is evidenced by the paucity of signals detected in between the steel and surface, demonstrating that the BlueInk also acts as a good anti-diffusion barrier. For SU8, these characterizations have not been carried out due to the high charging as a result of the highly insulative properties of the layer.

\subsection{Dielectric behaviour of ILs}

The dielectric behaviour of the ILs has been evaluated by measuring the leakage current and by detection of a breakdown potential. Through breakdown tests, it was shown that the dielectric coatings (sol-gel, BlueInk and SU8) passed well above the threshold of 40V. In the case of sol-gel samples, values of $53 \mathrm{~V}$ were obtained. BlueInk coatings showed breakdown potentials above $500 \mathrm{~V}$. As qualitative test, the leakage current was measured by voltage sweeping from $-40 \mathrm{~V}$ to $+40 \mathrm{~V}$ in steel/IL systems with evaporated silver or aluminium electrodes. Table II shows the achieved values for all the tested samples. This 
supports the breakdown tests confirming that these ILs are suited as electrical insulator layers for BIPVs on steel substrates, with few pin holes present in the films.

\subsection{Photovoltaic cells}

410 Solar cells $\left(1 \mathrm{~cm}^{2}\right)$ were manufactured on all four types of steel and three different IL 411 coating combinations. This was undertaken for both a-Si:H solar cells and OPVs. The 412 results are summarised in Table III and example current density-voltage (JV) 413 characteristics are shown for solar cells manufactured on $\mathrm{SiO}_{\mathrm{x}}$-coated AISI430 in figure 4145 under AM1.5G illumination. It is worth noting that the efficiencies of both a-Si:H solar cells and OPVs are slightly lower than the state of the art in this field. The reason for this is twofold; firstly the solar cells are made on relatively large areas $\left(1 \mathrm{~cm}^{2}\right)$ so are more representative of module performance; secondly the device processing could be further optimised for this configuration.

\subsubsection{Performance of a-Si:H cells on IL-coated steel}

Solar cells based on a-Si:H were successfully deposited in steel/IL systems with $\mathrm{SiO}_{\mathrm{x}}$ solgel as the IL. As shown in Table III, a relative difference of less than $10 \%$ was found when compared to a solar cell made on the reference (glass) substrate using the same experimental procedure. These results confirms the suitability of the IL/steel substrate for a-Si:H solar cell integration. Although this result had been achieved before [9], it is important to remark that, in this case, the layer was deposited from an upscale process using a single spray step and a high speed curing cycle, instead of a three dip coating processes followed by a $1 \mathrm{~h} 30$ thermal treatment.

In the case of organic coatings (BlueInk and SU8), the steel/IL systems were firstly introduced in a PECVD high vacuum chamber in order to evaluate possible desorption of organic compounds that could induce future delamination of the solar cells. When the steel/IL systems with the BlueInk IL was introduced into the vacuum system, a loss of one order of magnitude in vacuum pressure resulted $\left(2.1 \times 10^{-6}\right.$ Torr instead of the base pressure of $2.0 \times 10^{-7}$ Torr). A high vacuum treatment at $180^{\circ} \mathrm{C}$ was carried out for 2 hours within the chamber. This thermal treatment allowed the improvement of the vacuum in the PECVD chamber to values close to $3.1 \times 10^{-7}$ Torr, which is within the limits of the 
experimental procedure as for those made onto the $\mathrm{SiO}_{\mathrm{x}}$ sol-gel examples. As shown in Table IV, it has been possible to manufacture working cells. However, the obtained efficiencies are around $1.67 \%$, much lower than the efficiencies corresponding to the glass reference. This result proves the viability of BlueInk as an IL for a-Si:H deposition, although the roughness appears to limit the values of efficiency, in particular showing a relatively low fill factor and poor shunt resistance.

Steel/IL samples using the SU8 IL layer were also introduced into the PECVD high vacuum chamber. However, a high desorption was registered just after the sample was introduced into the PECVD chamber (the pressure rose to $1.2 \times 10^{-5}$ Torr from the limit of $2.0 \times 10^{-7}$ Torr). As a result of the poor desorption properties, it was judged that the SU8 epoxy was not suitable for a-Si:H TFSC.

\subsubsection{Performance of OPVs on IL-coated steel}

Table III reports the power conversion efficiencies achieved for OPVs on the four steels coated with $\mathrm{SiO}_{x}$ sol-gel IL by spray coating. It is evident that the efficiencies achieved on steel (2.00-2.40\%) are lower than achieved on a standard OPV fabricated on glass $(2.90 \%)$. The results provide a comparison of the same active layer material system, but very different architecture owing to the different substrates and different direction of irradiation onto the cell. Despite the lower efficiency, the result highlights the compatibility of OPV onto steel substrate with a scalable $\mathrm{SiO}_{\mathrm{x}}$ sol-gel IL. Glass is a lowcost and slightly higher performing option but is not $R 2 R$ compatible which is a disadvantage for OPVs, as most groups tend to fabricate OPVs from solution processing on $\mathrm{R} 2 \mathrm{R}$ processing lines. In the case of the SU8 IL layer, the efficiency achieved is relatively similar to that achieved on the $\mathrm{SiO}_{x} \mathrm{IL}(2.42 \%)$. OPVs are unlikely to be made commercially onto glass substrates, as glass adds a limitation to two of the key advantages which the OPV technology provides: flexibility and low embodied energy per module. Therefore, a more commercially relevant comparison of OPV performance is conducted relative to substrates such as polyethylene terephthalate (PET) or polyethylene naphthalate (PEN), as is shown in Table IV. In comparison, the performance of OPVs on PEN and PET is $2.31 \%$ and $2.2 \%$, respectively. By comparison, OPVs made on steel have an intermediate efficiency; they are not better than those made on glass, but appear to work better than those manufactured on plastic substrates. Concerning organic coatings, the use of BlueInk led to unsuccessful results for the manufacturing of OPVs. This is 
470 likely to be due to the high surface roughness of this layer, which this group estimated as being twice that required for the deposition of OPV.

\subsection{Economic viability}

474 A cost analysis taking into account both the $\mathrm{SiO}_{\mathrm{x}}$ sol-gel (spray process) and the blue ink 475 (screen printing process) ILs was finally performed in order to report the economic viability of the Steel/IL prototypes. The detailed study of the economic feasibility of both IL is reported in a previous work [26]. In this work, the process has been extended to ascertain the costs involved in manufacturing a new BIPV product adopting a bottom up approach in alignment with Anderson [27], where each of the individual cost elements (materials, manufacturing fixed costs, plant capacity and operations/maintenance) were identified and included within the cost model. The cost analysis assumes the utilisation of a modern R2R production facility with a manufacturing plant capacity of $30 \mathrm{MW} / \mathrm{year}$ [28] to assure the most efficient and cost-effective means to develop the BIPV products. In that sense, a feed rate for both IL materials has been estimated at $12 \mathrm{~m} / \mathrm{min}$, taking 6.9 hours to process a $1500 \mathrm{~m}^{2}$ roll, or 2.3 hours for a $500 \mathrm{~m}^{2}$ roll (roll size dependant on material thickness). After estimations of the consumable investment $\left(0.12 € / \mathrm{m}^{2}\right.$ for blue ink and $0.23 € / \mathrm{m}^{2}$ for $\mathrm{SiO}_{\mathrm{x}}$ sol-gel $)$, the labour $\left(0.52 € / \mathrm{m}^{2}\right)$, the electricity $\left(0.15 € / \mathrm{m}^{2}\right)$ and the materials costs including wastage $\left(1.80 € / \mathrm{m}^{2}\right.$ for blue ink and $0.33 € / \mathrm{m}^{2}$ for $\mathrm{SiO}_{\mathrm{x}}$ solgel), total processing costs of $2.60 € / \mathrm{m}^{2}$ for Blue Ink and $1.24 € / \mathrm{m}^{2}$ for $\mathrm{SiO}_{\mathrm{x}}$ sol-gel were calculated.

\section{Conclusions}

The development of electrically insulative, ionic blocking, planarising 'intermediate layers' (ILs) opens the possibility of using low-cost steels for the deposition of TFSC and, in addition, allows for monolithically interconnected cells on this substrate. The results have been achieved using a wide range of low cost steels (bare low carbon, hot-dip low carbon and ferritic stainless) using an inorganic sol-gel coating and two commercial organic materials, a dielectric ink and a photoresist. 
499 In the case of sol-gel IL layers, a-Si:H solar cells have been manufactured with 500 efficiencies $(\eta=4.59 \%-5.56 \%)$ close to those achieved on a reference glass substrate $(\eta$ $501=5.51 \%)$. The sol-gel/steel combination has been used as a substrate for OPV 502 manufacturing, obtaining efficiencies between $2.00 \%$ and $2.40 \%$, marginally lower than 503 the efficiency obtained onto glass $(\eta=2.90 \%)$. These differences have been attributed to 504 surface roughness of the coating $\left(\mathrm{R}_{\mathrm{a}}=30 \mathrm{~nm}-60 \mathrm{~nm}\right)$ and different architecture of the 505 device.

506 When organic coatings have been considered, SU8 coatings show a significant 507 planarizing effect, with mean average roughness below 20nm. This enabled the deposition of OPVs on steel/SU8 systems with high efficiency $(\eta=2.29 \%-2.42 \%)$ when compared to a flexible substrate reference (PEN, $\eta=2.31 \%$ ). In the case of a-Si:H, desorption of this coating under initial vacuum conditions has not allowed the deposition of these cells. BlueInk organic coatings represent an alternative approach to obtain high

512 dielectric coatings by means of simple and inexpensive deposition processes (in particular, screen printing). However, the results show that further improvements in terms of planarity and roughness are still required for the deposition of TFSCs. In the first case, the a-Si:H cells show low fill factor $(\mathrm{FF}=30 \%)$ and, consequently, low efficiencies when compared to glass standard.

\section{Acknowledgements}

519 The research leading to these results has received funding from the European Union's Research Fund for Coal and Steel (RFCS) research programme under grant agreement no. RFSR-CT-2014-00014.

\section{References}

524 [1] J. Ilmarinen, 2010. Directive 2010/31/EU of the European Parliament and of the 525 Council of 19 May 2010 on the Energy Performance of Buildings (recast), Mita“ työkyky, 526 pp. 13-35.

527 [2] EUROPE 2020.A strategy for smart, sustainable and inclusive growth. 528 Communication from the Commission. European Commission. Brussels, 3.3.2010 
[3] P.R. Defaix. Technical potential for photovoltaics on buildings in the EU-27. Sol. Energy 86 (9), 2644-2653 (2012)

[4] A. Scognamiglio, H. N. Rostvik. Photovoltaics and zero energy buildings: a new opportunity and challenge for design. Progr. Photovolt.: Res. Appl. 21, 1319-1336 (2013)

[5] E. Biyik, M. Araz, A. Hepbasli, M. Shahrestani, R. Yao, L. Shao, E. Essah, A. C. Oliveira, T. Del Caño, E. Rico, J. L. Lechón, L. Andrade, A. Mendes, Y. Baver Atlı. A key review of building integrated photovoltaic (BIPV) systems. Engineering Science and Technology, an International Journal 20 (2017) 833-858

[6] H. Yu, Q. Wang, C. Lu, C. Wei. The research on a new type of BIPV modules constructed by thin-film photovoltaic panel (or module)/PU/color organiccoated steel plate, In: 2014 IEEE 40th Photovolt Spec Conf PVSC 2014 2014, 2724-2727, doi:http://dx.doi.org/10.1109/PVSC.2014.6925492.

[7] J. H. Song, Y. S. An, S. G. Kim, S. J. Lee, J. H. Yoon, Y. K. Choung. Power output analysis of transparent thin-film module in building integrated photovoltaic system (BIPV). Energ. Buildings 40, 11, 2067-2075 (2008)

[8] Hagar Elarga, Angelo Zarrella, Michele De Carli. Dynamic energy evaluation and glazing layers optimization of façade building with innovative integration of PV modules. Energ. Buildings 111, 468-478 (2016)

[9] A. L. Martínez, A. Menéndez, P. Sánchez, L. J. Andrés, M. F. Menéndez, J. Izard, B. Sánchez, D. Gómez. Solar photovoltaic technology on rough low carbon steel substrates for building integrated photovoltaics: A complete fabrication sequence. Sol. Energy 124, 216-226 (2016)

[10] L. Zortea, S. Nishiwaki, T. P. Weiss, S. Hass, J. Perrenoud, L. Greuter, T. Feurer, G. Palaniswamy, S. Buecheler, A. N. Tiwari. Cu(In,Ga)Se2 solar cells on low cost mild steel substrates. Solar Energy 175, 25-30 (2018)

[11] K. Kyoung-Bo, K. Moojin, L. Hong-Chan, P. Sang-Wook, J. Chan-Wook. Copper indium gallium selenide (CIGS) solar cell devices on steel substrates coated with thick SiO2-based insulating material. Materials research bulletin, 85, 168-175 (2017)

[12] W Thongkam et al. Enhancing efficiency of $\mathrm{Cu}(\mathrm{In}, \mathrm{Ga}) \mathrm{Se}_{2}$ solar cells on flexible stainless steel foils using NaF co-evaporation, Solar Energy, 92, 189-195 (2013)

[13] S.J. Yun, Y.J. Lee, J.W. Lim, J.H. Yun, J. Baek, K.B. Kim, Y.J. Park, Insulating oxide buffer layer formed by sol-gel method for planarization of stainless steel substrate of a-Si:H thin film solar cell, Materials research bulletin, 47, 3044-3047 (2012)

[14] S. J. Lee, Y. H. Chen, S. C. Hu, Y. C. Lin, J. W. Chang, T. L. Poon, W. C. Ke. Improved performance of amorphous $\mathrm{Si}$ thin-film solar cells on 430 stainless steel substrate by an electrochemical mechanical polishing process. J. Alloys Comp., 558 (5), 95-98 (2013) 
[15] C. López, M.F. Menéndez, L.J. Andrés, A. Menéndez, P. Sanchez, M.D. Alba, E. Sánchez, J.M. Deldado, Enhancement of dielectric barrier layer properties by sol-gel and PECVD stacks, Surface and coatings technology, 305, 36-40, (2016)

[16] M. G. Kang, N. G. Park, K. S. Ryu, S. H. Chang, K. J. Kim. A 4.2\% efficient flexible dye-sensitized $\mathrm{TiO} 2$ solar cells using stainless steel substrate. Sol. Energy Mater. Sol. Cells 90 (5), 574-581 (2006)

[17] M. M. Aliyu, M. A. Islam, N. R. Hamzah, M. R. Karim, M. A. Matin, K. Sopian, N. Amin. Recent Developments of Flexible CdTe Solar Cells on Metallic Substrates: Issues and Prospects. Int. J. Photoenergy, Volume 2012 (2012), Article ID 351381

[18] Y. Galagan, D. J. D. Moet, D. C. Hermes, P. W. M. Blom, R. Andriessen. Large area ITO-free organic solar cells on steel substrate. Organic Electronics 13 (12), 3310-3314 (2012)

[19] D. Gupta, M. M. Wienk, R. A. J. Janssen. Efficient Polymer Solar Cells on Opaque Substrates with a Laminated PEDOT:PSS Top Electrode. Adv. Ener. Mat., 3 (6), 782787 (2013)

[20] L. S. Pali, P. Ganesan, A. Garg. Inverted P3HT:PCBM organic solar cells on low carbon steel substrates, Sol. Energy 133, 339-348 (2016)

[21] Z. Ding, V. Stoichkov, M. Horie, E. Brousseau, J. Kettle. Spray coated silver nanowires as transparent electrodes in OPVs for Building Integrated Photovoltaics applications. Sol. Energy Mater. Sol. Cells 157, 305-3011 (2016)

[22] K. Sun, F. Liu, C. Yan, F. Zhou, J. Huang, Y. Shen, R. Liu, X. Hao. Influence of sodium incorporation on kesterite $\mathrm{Cu}_{2} \mathrm{ZnSnS}_{4}$ solar cells fabricated on stainless steel substrates. Sol. Energy Mater. Sol. Cells 157, 565-571 (2016)

[23] MKM GmbH private communication

[24] B. Fernández, R. Pereiro and A. Sanz-Medel. Glow discharge analysis of nanostructured materials and nanolayers - a review, Anal. Chim. Acta, 679, 7-16 (2010)

[25] M. Hohl, A. Kanzari, J. Michler, Th. Nelis, K. Fuher, M. Gonin, Pulsed r.f.-glowdischarge time-of-flight mass spectrometry for fast surface and interface analysis of conductive and non-conductive materials, Surf. Interface Anal, 38, 292-295 (2006)

[26] L. Hughes, N. Bristow, T. Korochkina, P. Sanchez, D. Gomez, J. Kettle, D. Gethin Assessing the potential of steel as a substrate for building integrated photovoltaic applications Applied Energy 229, 209-223 (2018)

[27] Anderson J. Determining manufacturing costs. Chem Eng Prog, 105, 27-31 (2009)

[28] Green MA, Emery K, Hishikawa Y, Warta W, Dunlop E, Levi D, et al. Solar cell efficiency tables (version 49). Prog Photovolt Res Appl. 25, 3-13 (2017) 
601

602 


\section{Table captions}

605 Table I. Chemical composition of selected steel substrates samples used for this 606 work

607 Table II. Leakage currents (in nA) corresponding the steel/IL systems developed in this 608 work

609 Table III. Photovoltaic performance parameters obtained from illumination under 6101 Sun AM1.5G spectrum for the a-Si:H and OPV cells on different steel/IL 611 systems

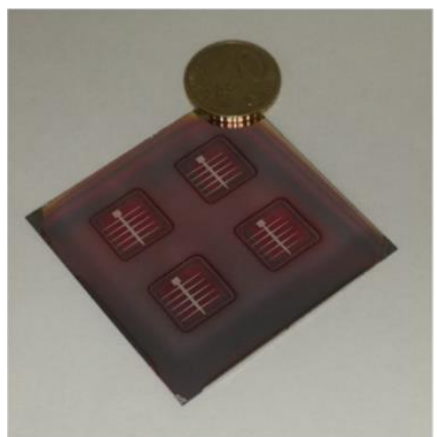

(a)

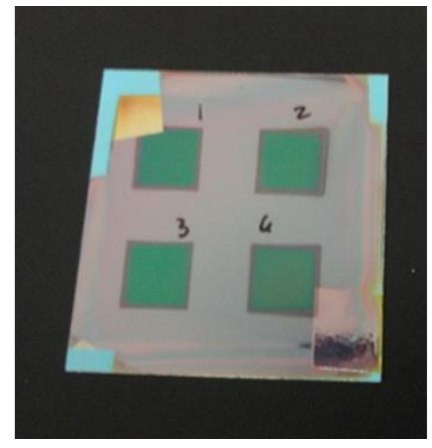

(b)

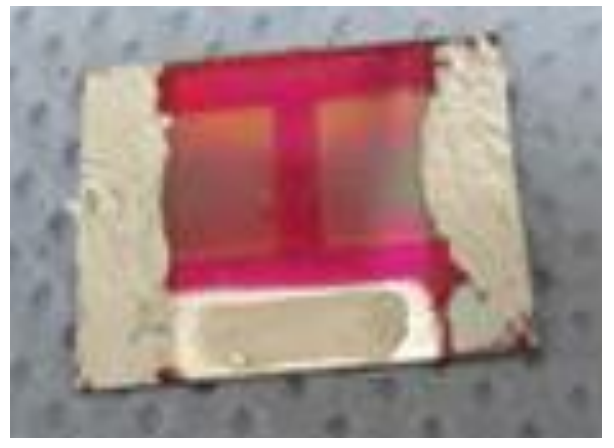

(c)

617 Figure 1. (a) a-Si:H solar cells deposited on AISI430/SiO ${ }_{x}$ sol-gel (b) onto BlueInk and 618 (c) Organic photovoltaic deposited onto AISI430/SU8 


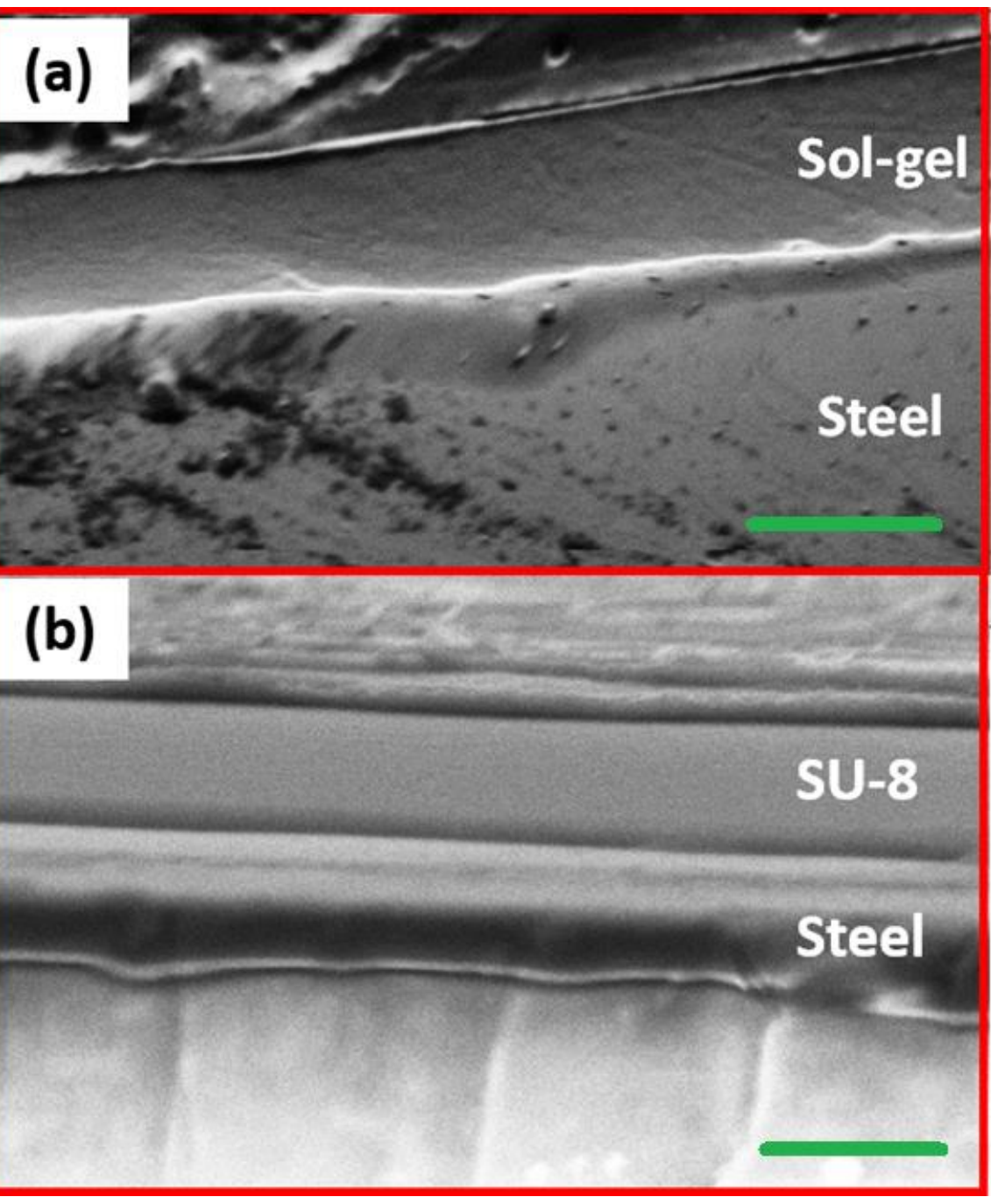

Figure 2. FE-SEM cross sectional image of AISI430 steel samples coated with (a) $\mathrm{SiO}_{\mathrm{x}}$ sol-gel (scale bar $=3 \mu \mathrm{m})$ and (b) SU8 intermediate layers $($ scale bar $=60 \mu \mathrm{m})$

623 


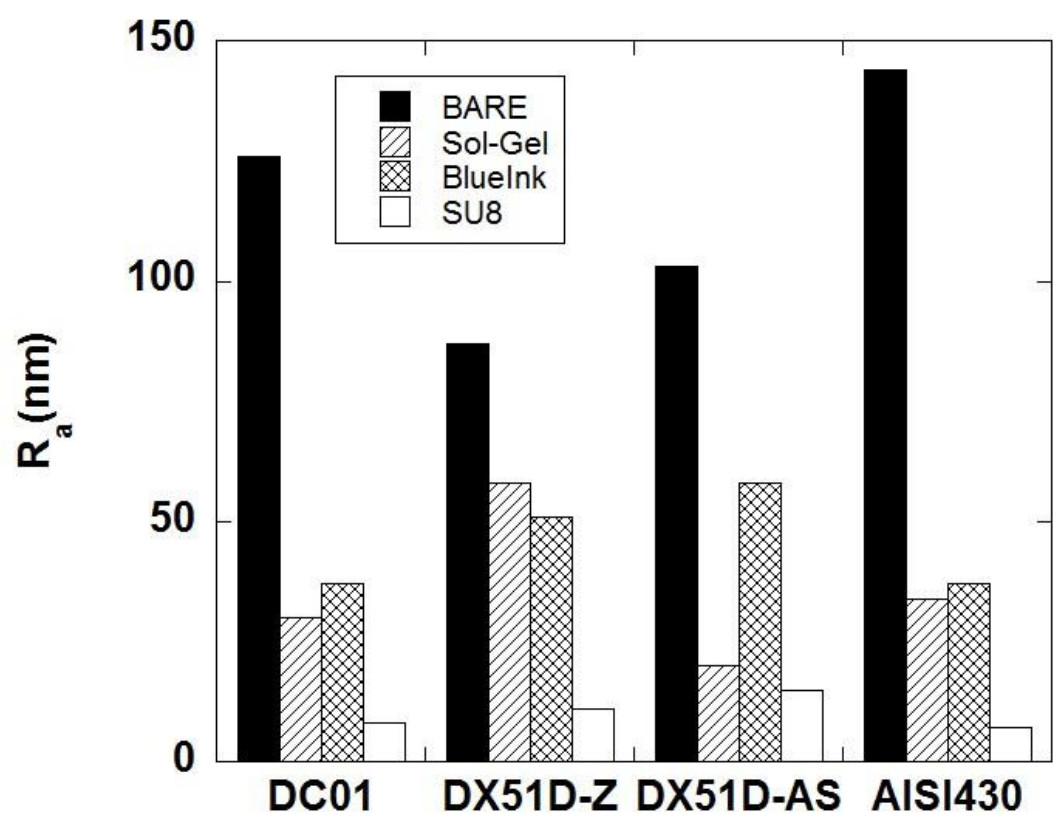

625

(a)

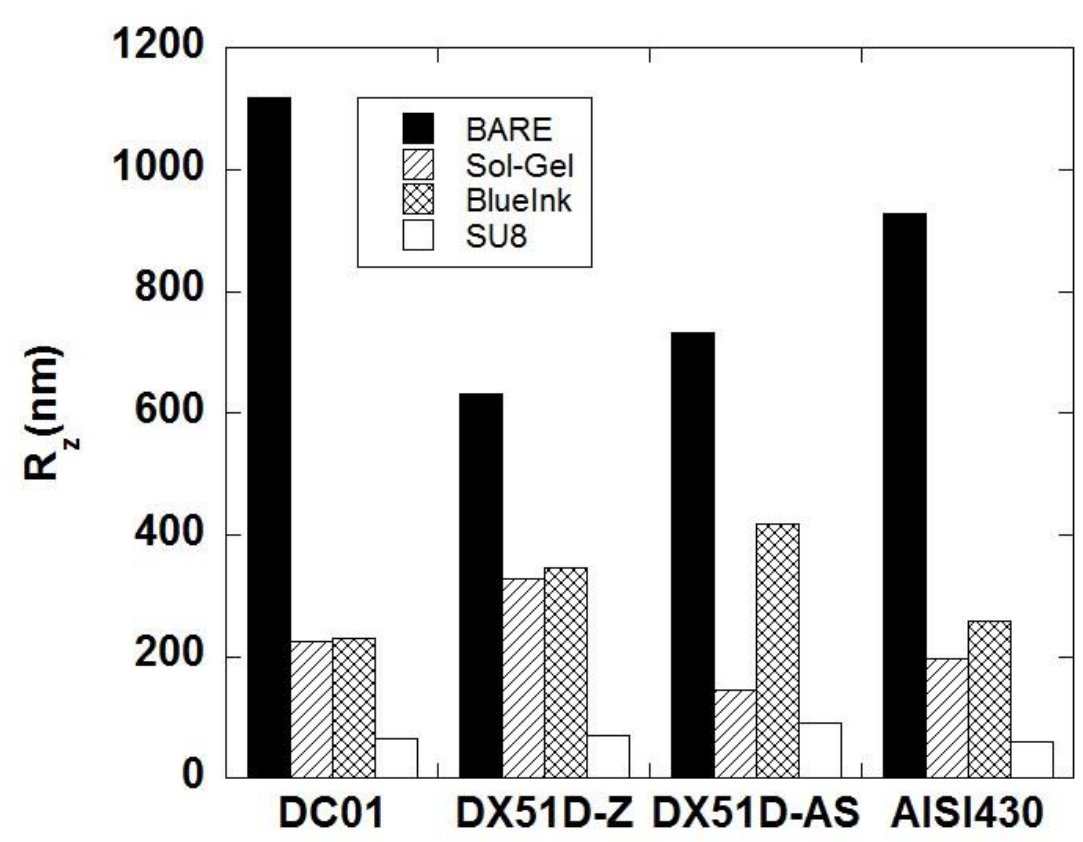

627

(b)

Figure 3. (a) Mean ( $\left.\mathrm{R}_{\mathrm{a}}\right)$ and (b) peak-to-valley $\left(\mathrm{R}_{\mathrm{z}}\right)$ roughness of bare 

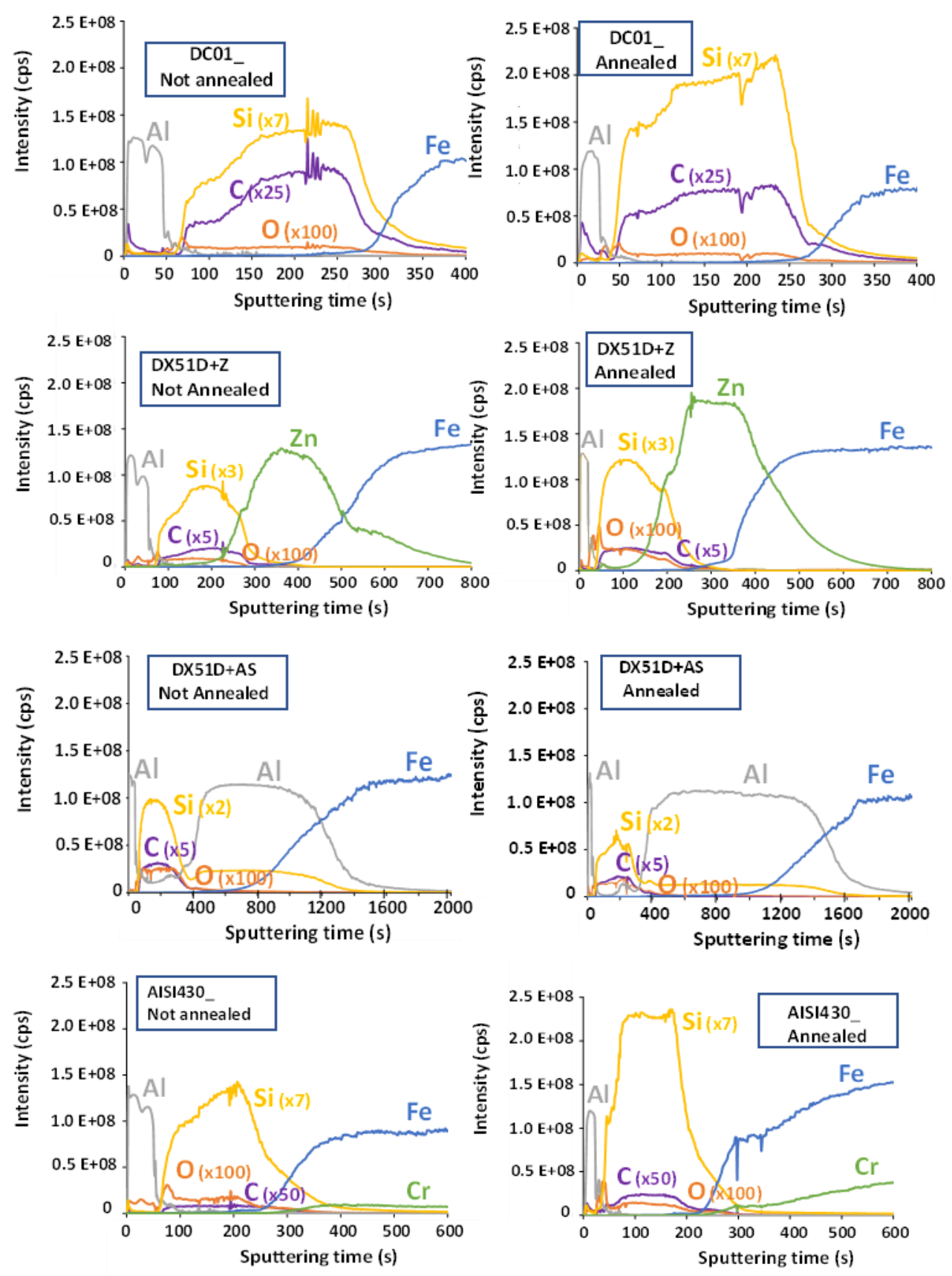

634 Figure 4 Qualitative depth profiles obtained using glow discharge time of flight mass 635 spectroscopy (GD-ToF-MS) of non annealed and annealed for all steels/SiO ${ }_{x}$ sol-gel 636 samples used in this work, with Al top electrodes to replicate the structure of the solar 637 cell. The $\mathrm{SiO}_{\mathrm{x}}$ layer shows extremely good barrier layer performance. 
640

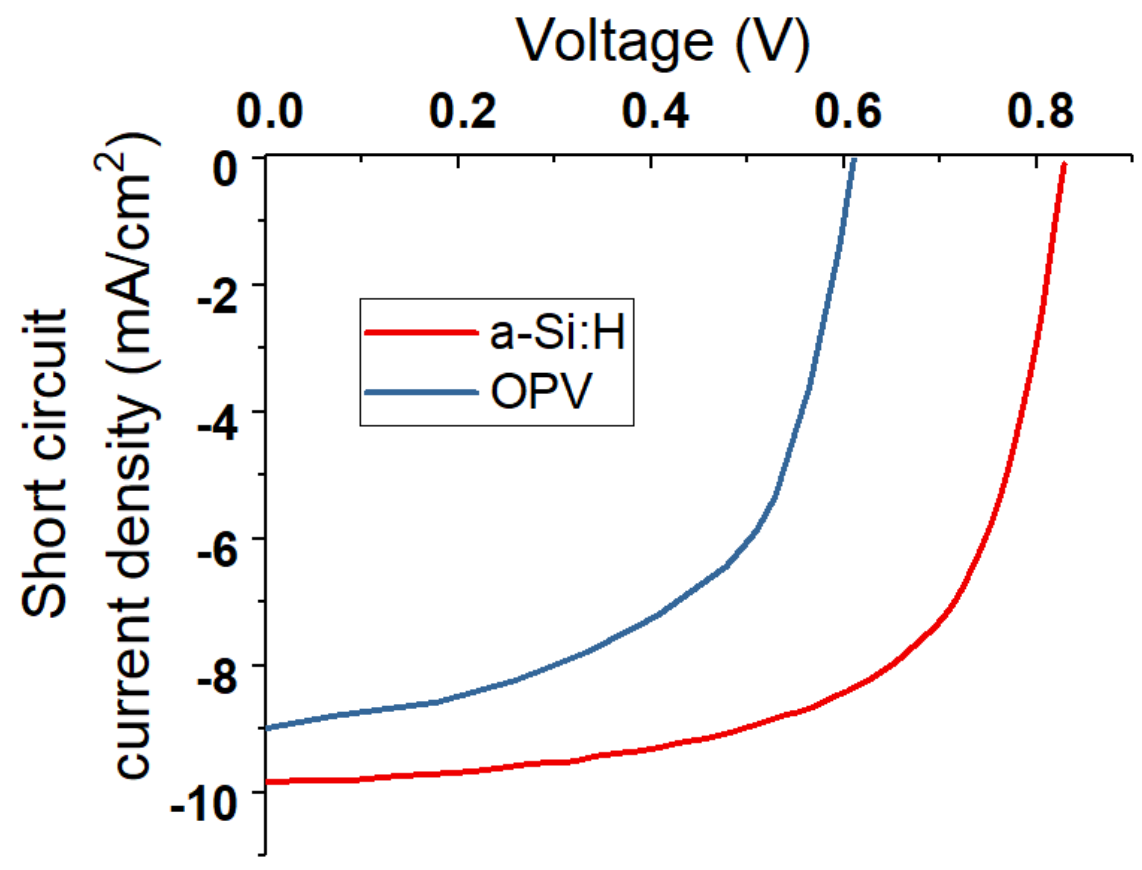

Figure 5. Sample J-V curves of solar cells using data of a-Si:H solar cells and OPV onto AISI430 substartes after a $\mathrm{SiO}_{\mathrm{x}}$ sol-gel IL has been applied

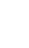

\begin{tabular}{lllccccccc}
\hline & \multicolumn{7}{c}{ Material } & \multicolumn{7}{c}{ Chemical composition \%(wt.) } \\
\cline { 2 - 8 } & C & Si & Mn & P & S & Cr & Ti \\
\hline \hline$\# 01$ & $\begin{array}{l}\text { Bare Steel } \\
\text { (DC01) }\end{array}$ & $\leq 0.12$ & $\leq 0.3$ & $\leq 0.6$ & $\leq 0.045$ & $\leq 0.045$ & - & - \\
\hline$\# \mathbf{0 2}$ & $\begin{array}{l}\text { Hot-dip zinc coated } \\
(\text { DX51D+Z) }\end{array}$ & $\leq 0.18$ & $\leq 0.5$ & $\leq 1.2$ & $\leq 0.12$ & $\leq 0.045$ & - & $\leq 0.3$ \\
\hline$\# \mathbf{0 3}$ & $\begin{array}{l}\text { Hot-dip Al-Si coated } \\
\text { (DX51D+AS) }\end{array}$ & $\leq 0.18$ & $\leq 0.5$ & $\leq 1.2$ & $\leq 0.12$ & $\leq 0.045$ & - & $\leq 0.3$ \\
\hline$\# \mathbf{0 4}$ & $\begin{array}{l}\text { Stainless Steel } \\
\text { (AISI430) }\end{array}$ & $\leq 0.08$ & $\leq 1.0$ & $\leq 1.0$ & $\leq 0.04$ & $\leq 0.03$ & $16.0-18.0$ & - \\
\hline \hline
\end{tabular}

648

${ }^{1}$ Hot-dip Zn: Zn $\geq 98 \%$

$649{ }^{2}$ Hot-dip Al-Si: Al 85.5\%-88.5\% + Si 9\%-11\% + Fe 2.5\%-3.5\%

650 
Table II. Leakage currents (in $\mathrm{nA} / \mathrm{cm}^{2}$ ) corresponding the steel/IL systems developed in this work

\section{Leakage current $\left(\mathrm{nA} / \mathrm{cm}^{2}\right)$}

\begin{tabular}{|c|c|c|c|c|c|c|c|}
\hline & Material & $\begin{array}{c}\text { Sol-gel } \\
\text { (Ag) }\end{array}$ & $\begin{array}{c}\text { Sol-gel } \\
\text { (Al) }\end{array}$ & $\begin{array}{c}\text { BI } \\
(\mathbf{A g})\end{array}$ & $\begin{array}{c}\text { BI } \\
\text { (Al) }\end{array}$ & $\begin{array}{l}\text { SU8 } \\
\text { (Ag) }\end{array}$ & $\begin{array}{l}\text { SU8 } \\
\text { (Al) }\end{array}$ \\
\hline \#01 & DC01 & 35.17 & 35.00 & - & - & 27.29 & 41.58 \\
\hline$\# 02$ & DX51D+Z & 36.29 & 36.25 & - & - & 18.96 & 30.08 \\
\hline$\# 03$ & DX51D+AS & 31.00 & 30.83 & - & - & 16.17 & 23.13 \\
\hline$\# 04$ & AISI430 & 25.92 & 29.04 & - & - & 11.54 & 12.46 \\
\hline
\end{tabular}

654

655 
Table III. Characteristic parameters obtained from current-voltage curves corresponding a-Si:H and OPV cells on different steel/IL systems. Averages are taken from 6 devices for all reported in this work and standard deviations are also reported

\begin{tabular}{|c|c|c|c|c|c|c|c|c|c|}
\hline & & \\
\hline & & \multicolumn{4}{|c|}{ a-Si:H* } & \multicolumn{4}{|c|}{ Organic PV } \\
\hline & & $\begin{array}{c}\mathbf{J S C} \\
(\mathrm{mA} / \mathrm{c} \\
\left.\mathrm{m}^{2}\right) \\
\end{array}$ & $\begin{array}{l}\text { VoC } \\
(\mathrm{mV})\end{array}$ & $\begin{array}{l}\text { FF } \\
(\%)\end{array}$ & $\eta(\%)$ & $\begin{array}{c}\mathbf{J S C} \\
\left(\mathrm{mA} / \mathrm{cm}^{2}\right)\end{array}$ & $\begin{array}{l}\text { VoC } \\
(\mathrm{mV})\end{array}$ & $\begin{array}{l}\text { FF } \\
(\%)\end{array}$ & $\boldsymbol{\eta}(\%)$ \\
\hline \multirow{5}{*}{$\begin{array}{r}\mathrm{SiO} \\
\times \mathrm{SG}\end{array}$} & $\begin{array}{l}\text { Reference } \\
\text { (glass) }\end{array}$ & $\begin{array}{l}11.03 \\
\pm 0.35\end{array}$ & $813 \pm 3$ & $55 \pm 1$ & $\begin{array}{c}5.51 \pm \\
0.21\end{array}$ & $\begin{array}{c}9.88 \\
\pm 0.20\end{array}$ & $590 \pm 2$ & $\begin{array}{c}59 \\
\pm 4.0\end{array}$ & $\begin{array}{c}2.90 \\
\pm 0.34\end{array}$ \\
\hline & DC01 & $\begin{array}{l}10.62 \\
\pm 0.94\end{array}$ & $839 \pm 4$ & $56 \pm 4$ & $\begin{array}{c}5.56 \pm \\
0.16\end{array}$ & $\begin{array}{c}8.46 \\
\pm 0.30\end{array}$ & $560 \pm 5$ & $\begin{array}{c}45 \\
\pm 4.2\end{array}$ & $\begin{array}{c}2.15 \\
\pm 0.46\end{array}$ \\
\hline & DX51D+Z & $\begin{array}{l}10.22 \\
\pm 0.55\end{array}$ & $832 \pm 9$ & $58 \pm 4$ & $\begin{array}{c}5.41 \pm \\
0.12\end{array}$ & $\begin{array}{c}8.21 \\
\pm 0.40\end{array}$ & $550 \pm 3$ & $\begin{array}{c}44 \\
\pm 4.9\end{array}$ & $\begin{array}{c}2.00 \\
\pm 0.27\end{array}$ \\
\hline & $\begin{array}{l}\text { DX51D+A } \\
S\end{array}$ & $\begin{array}{l}10.65 \\
\pm 0.21\end{array}$ & $835 \pm 7$ & $47 \pm 2$ & $\begin{array}{c}4.59 * \\
* \pm 0.1 \\
6\end{array}$ & $\begin{array}{c}8.70 \\
\pm 0.40\end{array}$ & $550 \pm 3$ & $\begin{array}{c}47 \\
\pm 2.9\end{array}$ & $\begin{array}{l}2.23 \\
\pm 0.25\end{array}$ \\
\hline & AISI430 & $\begin{array}{c}9.92 \pm \\
0.61\end{array}$ & $820 \pm 17$ & $61 \pm 3$ & $\begin{array}{c}5.53 \pm \\
0.26\end{array}$ & $\begin{array}{c}9.20 \\
\pm 0.50\end{array}$ & $530 \pm 3$ & $\begin{array}{c}48 \\
\pm 6.0\end{array}$ & $\begin{array}{c}2.40 \\
\pm 0.52\end{array}$ \\
\hline \multirow{4}{*}{$\begin{array}{l}\text { BI } \\
\text { BI }\end{array}$} & בDC01 & - & - & - & - & & & & \\
\hline & DX51D+Z & - & - & - & - & & & & \\
\hline & $\begin{array}{l}\text { DX51D+A } \\
\text { S }\end{array}$ & - & - & - & - & & & & \\
\hline & AISI430 & $\begin{array}{c}6.93 \pm \\
1.12\end{array}$ & $750 \pm 82$ & $29 \pm 1$ & $\begin{array}{c}1.67 \pm \\
0.43 * \\
*\end{array}$ & $\begin{array}{c}7.63 \\
\pm 0.22\end{array}$ & $510 \pm 5$ & $\begin{array}{c}38 \\
\pm 4.0\end{array}$ & $\begin{array}{c}1.48 \\
\pm 0.20\end{array}$ \\
\hline \multirow{5}{*}{ SU8 } & $\begin{array}{l}\text { Reference } \\
(\mathrm{PEN})\end{array}$ & \multirow{5}{*}{\multicolumn{4}{|c|}{$\begin{array}{c}\text { Desorption at } \\
\text { required vacuum } \\
\text { level }\end{array}$}} & $\begin{array}{c}9.01 \\
\pm 0.18\end{array}$ & $570 \pm 2$ & $\begin{array}{c}45 \\
\pm 5.0\end{array}$ & $\begin{array}{c}2.31 \\
\pm 0.30\end{array}$ \\
\hline & DC01 & & & & & $\begin{array}{c}9.54 \\
\pm 0.19\end{array}$ & $546 \pm 10$ & $\begin{array}{c}55 \\
+5.8\end{array}$ & $\begin{array}{c}2.42 \\
\pm 0.22\end{array}$ \\
\hline & DX51D+Z & & & & & $\begin{array}{c}8.90 \\
\pm 0.20\end{array}$ & $546 \pm 8$ & $\begin{array}{c}47 \\
\pm 6.0\end{array}$ & $\begin{array}{c}2.29 \\
\pm 0.31\end{array}$ \\
\hline & $\begin{array}{l}\text { DX51D+A } \\
\text { S }\end{array}$ & & & & & $\begin{array}{c}9.01 \\
\pm 0.29\end{array}$ & $540 \pm 10$ & $\begin{array}{c}47 \\
\pm 3.0\end{array}$ & $\begin{array}{c}2.30 \\
\pm 0.20\end{array}$ \\
\hline & AISI430 & & & & & $\begin{array}{c}8.94 \\
\pm 0.09\end{array}$ & $540 \pm 0.2$ & $\begin{array}{c}49 \\
\pm 2.5\end{array}$ & $\begin{array}{r}2.35 \\
\pm 0.18\end{array}$ \\
\hline
\end{tabular}




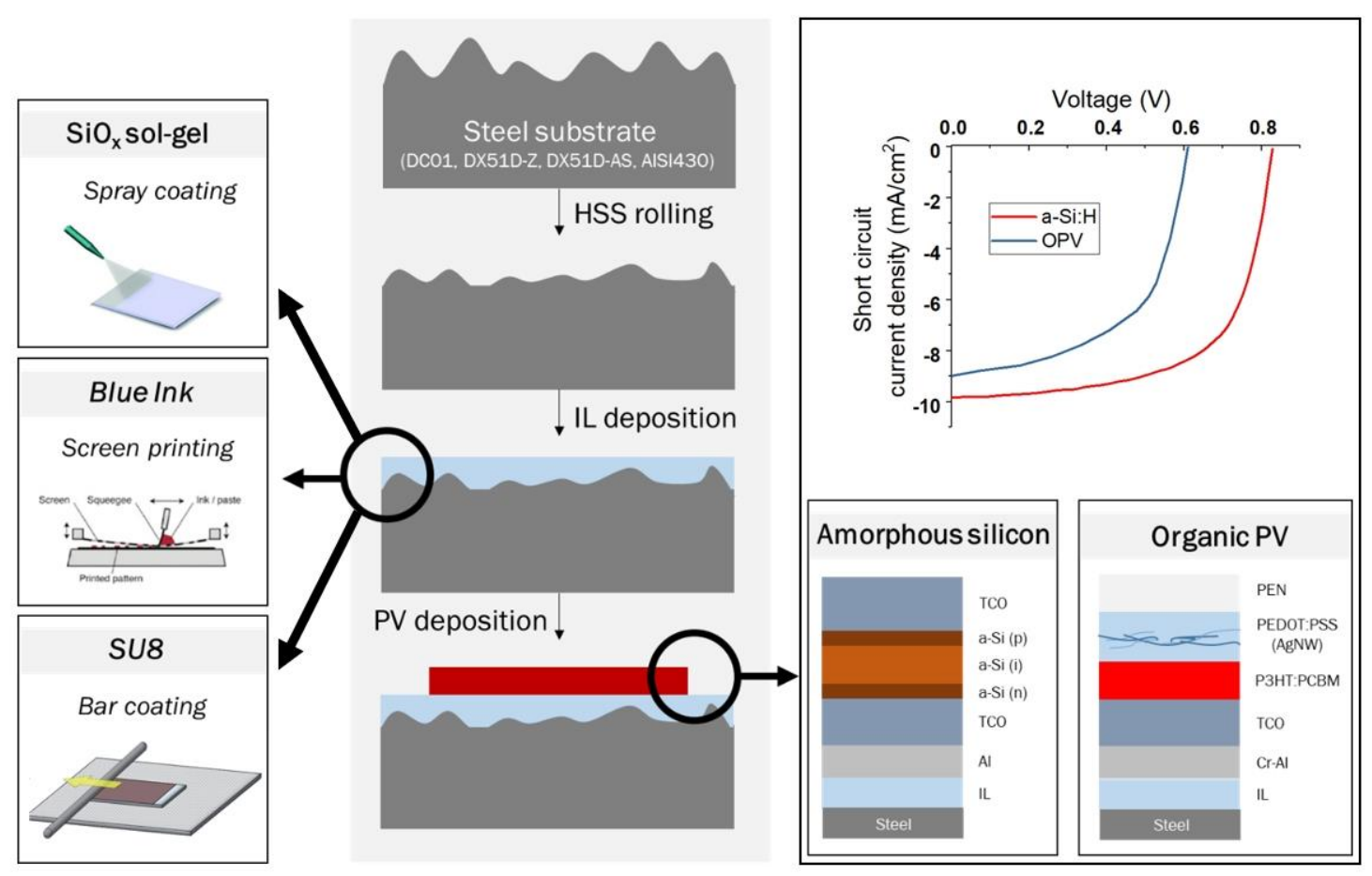

